Chirurgia (2018) 113: 405-411

No. 3, May - June

Copyright@ Celsius

http://dx.doi.org/10.21614/chirurgia.113.3.405

\title{
Very Early Onset Pancreatic Adenocarcinoma - Clinical Presentation, Risk Factors and Therapeutic Options
}

\author{
Ștefania Bunduc', Răzvan lacob ${ }^{1,2}$, Roxana Costache ${ }^{1}$, Bianca Stoica', Cristina Radu ${ }^{2,3}$, and Cristian Gheorghe ${ }^{1,2}$ \\ ${ }^{1}$ Center for Digestive Diseases and Liver Transplantation, Fundeni Clinical Institute, Bucharest, Romania \\ 2"Carol Davila" University of Medicine and Pharmacy, Bucharest, Romania \\ 3"Sfânta Maria" Clinical Hospital, Bucharest, Romania
}

Corresponding author:

Cristina Radu, MD, PhD Student

Gastroenterology specialist

"Carol Davila" University of Medicine and Pharmacy

"Stânta Maria Hospital"

37-39 Ion Mihalache Blv, Bucharest

Romania

E-mail: cristinaelenaradu@gmail.com

Received: 17.04 .2018

Accepted: 03.06.2018

\section{Rezumat}

Adenocarcinomul pancreatic cu debut precoce - particulatități clinice, factori de risc și abordare terapeutică

Introducere: Cancerul pancreatic este diagnosticat cel mai frecvent în decada a şaptea de viață, însă tumorile descoperite la vârste tinere au un impact mai mare privind numărul potențial de ani de viață pierduți. Scopul studiului nostru a fost de a cerceta diferențele din punct de vedere epidemiologic, clinic şi terapeutic, la pacienții cu adenocarcinoame pancreatice diagnosticați înainte de 45 de ani (Grup 1 - G1) față de cei diagnosticați după 45 de ani (Grup 2 -G2).

Metode: S-a efectuat un studiu retrospectiv în care au fost înregistrate standardizat, în foi de calcul Excel, toate cazurile de tumori maligne pancreatice diagnosticate într-un centru tertiar de gastroenterologie în perioada 01.01.2015-31.12.2017. Analiza statistică a inclus doar cazurile de adenocarcinoame pancreatice documentate histopatologic si s-a efectuat utilizand software-ul NCSSv9. Pentru compararea variabilelor calitative s-au folosit testele Chi2 sau Fisher Exact, după caz, considerându-se p $<0.05$ semnificativ statistic.

Rezultate: In perioada studiului au fost diagnosticați 296 pacienți cu tumori maligne pancreatice în centrul nostru, dintre care 183 cazuri cu documentare histopatologică - $80.87 \%$ adenocarcinoame, $17.5 \%$ tumori neuroendocrine, două cazuri de LMNH şi un caz de MANEC. În cohorta analizată au fost 24 (16.22\%) adenocarcinoame pancreatice dianosticate înainte de 45 ani. Antecedentele heredocolaterale de cancer de pancreas $(33.3 \%$ vs $1.03 \%, \mathrm{p}=0.0004)$ 
şi consumul de alcool $(42.86 \%$ vs $5.41 \%$, p=0.01) s-au înregistrat semnificativ mai frecvent la tineri. Durerea a fost raportata ca simptom principal cu prevalență semnificativ crescută de către pacienții tineri $(60 \%$ vs $22.94 \%, \mathrm{p}=0.006)$. In $\mathrm{G} 1$ tumorile au fost localizate predominant la nivel cefalic (56.52\%) în timp ce în G2 a predominat localizarea corporeala $(52.07 \%, \mathrm{p}=0.02)$. Nu s-au înregistrat diferențe semnificative în privința metodelor terapeutice şi a mortalității între cele două grupuri, deşi rezectia cu intentie radicala s-a efectuat mai frecvent la tineri (33.3\% vs 22.69\%).

Concluzii: În studiul nostru, factorii de risc asociați cu diagnosticul adenocarcinomului pancreatic sub vârsta de 45 de ani au fost consumul de alcool şi istoricul familial de cancer de pancreas. Durerea a fost principalul simptom acuzat de pacienții tineri la diagnostic. Nu s-au înregistrat diferențe semnificative în abordarea terapeutică în funcție de vârstă.

Cuvinte cheie: cancer de pancreas, vârstă, factori de risc

\section{Abstract}

Background: Pancreatic cancer (PC) is usually diagnosed in the $7^{\text {th }}$ decade, but cases diagnosed in younger patients are associated with a greater disease burden, through the potential years of life lost. The aim of our study was to compare the differences in risk factors, clinical presentation and treatment options between patients diagnosed with pancreatic adenocarcinoma below 45 years of age (very early onset pancreatic adenocarcinoma - VEOPC), and those diagnosed over 45 years.

Methods: A retrospective study has been conducted by registering in standardized Excel Worksheets all PC cases diagnosed in our tertiary referral center between 01.01.2015 and 31.12.2017. Only patients with a documented diagnosis of pancreatic adenocarcinoma (PDAC) were included in the statistical analysis that has been conducted using the NCSS v9 Statistical Software package. Categorical data have been compared using Chi2 test or Fisher Exact as appropriate, with a statistical significance $\mathrm{p}$ value $<0.05$.

Results: There were 296 patients diagnosed with pancreatic solid tumors during the study period, 183 cases with documented histology: 80.87\% PDAC, 17.5\% neuroendocrine tumors, 2 cases of LMNH and 1 MANEC tumor. In our study group there were 24 patients (16.22\%) with VEOPC. Family history of pancreatic neoplasia (33.3\% vs $1.03 \%, \mathrm{p}=0.0004)$ and alcohol consumption $(42.86 \%$ vs $5.41 \%, \mathrm{p}=0.01$ ) were significantly more prevalent in young patients. Pain, as primary symptom, was reported at higher rates in patients with VEOPC ( $60 \%$ vs $22.94 \%, \mathrm{p}=0.006)$. Tumors were more frequently located in the head of the pancreas in younger patients $(56.52 \%)$ and in the body of the pancreas in older patients $(52.07 \%, \mathrm{p}=0.02)$. There was no significant difference in therapy or death rate during follow-up period between the two study groups, although patients diagnosed under 45 years were more frequently subjected to a radical resection (33.3\% vs $22.69 \%)$.

Conclusions: Our study has identified alcohol consumption and family history of pancreatic neoplasia as risk factors for VEOPC. Pain is the primary symptom at diagnosis in young patients with PDAC. In our cohort, therapeutic options do not differ significantly in PDAC patients with age of onset.

Key words: early onset, pancreatic cancer, risk factors

\section{Introduction}

Pancreatic cancer is a highly lethal disease, characterized by early systemic spread and rapid progression after diagnosis (1). It is the thirteenth most common cancer worldwide with an incidence of about 8 to 10 cases per 105 population per year in the developed 
world (2). The prognosis is dismal and has not improved over the past 40 years, with about $5 \%$ life expectancy 5-years after diagnosis (3).

Mean age at onset of pancreatic cancer (PC) is around 70 years (3). Pancreatic cancer cases diagnosed at younger ages - before 60 years of age are defined as early onset pancreatic cancer (EOPC) or very early onset PC (VEOPC) for those diagnosed before 45 years $(4,5)$. Large epidemiological studies reported that even if EOPC represents only 5-10\% of all PCs it contributes significantly to the total burden of the disease, because of the greater number of years of potential life lost (YPLL) $(4,5)$.

Early onset pancreatic cancer research is limited and information on epidemiology, etiology or prognosis is sometimes conflicting. The ratio of early-to-late onset $\mathrm{PC}$ varies widely across countries and an excess of EOPC is seen in Central/Eastern European countries; in this region, the proportion of YPLL from EOPC could represent as much as one-third of the total mortality burden from PC (4). A better characterization of EOPC and VEOPC could lead to the detection of specific risk factors possibly leading to better therapeutic strategies. Therefore we have conducted a retrospective analysis over a 3-year time period aimed to investigate the differences in clinical presentation, risk factors and therapeutic strategy in patients diagnosed in our Tertiary Gastroenterology Center with pancreatic adenocarcinoma aged under 45 years in comparison to those diagnosed beyond this age.

\section{Methods}

\section{Study design}

Data was collected retrospectively from our hospital computerized database. All cases of pancreatic malignant tumors diagnosed during 01.01.2015 - 31.12.2017 in our Tertiary Gastroenterology Department were registered in standardized Excel Worksheets. Only patients with a documented histological diagnosis of pancreatic adenocarcinoma (PDAC) were included in the final statistical analysis.

\section{Study Population}

The patient cohort with histologically proven PDAC was divided into two groups - Group 1 (G1) - patients 45 years old or younger and Group 2 (G2) patients older than 45 years. We have recorded information about: demographics - age, sex; risk factors - smoking, alcohol consumption, personal history of chronic pancreatitis, family history of pancreatic cancer, diabetes, obesity; clinical presentation - jaundice, pain, weight loss, nausea, anorexia; tumor features - location (head/body/tail), histological type, evidence of vascular invasion, presence of metastases and about treatment potentially curative resection, adjuvant chemotherapy, palliative treatment, best supportive care (BSC); all deaths during study period were also recorded.

\section{Statistical Analysis}

Statistical analysis was performed using NCSS Statistical Software version 9 (NCSSv9). To evaluate the differences between G1 and G2, Chi2 test or Fisher Exact were used, as appropriate, to compare categorical data. Statistical significance was considered for a two-tailed $\mathrm{p}$ value of less than 0.05 .

\section{Results}

\section{Clinical presentation and risk factors}

There were 296 cases of pancreatic malignancies admitted in our Department during study period and 183 cases had a documented histology. Our study group comprised 148 patients with histologically proven PDAC. Twenty four patients $(16.2 \%)$ were VEOPCs and were included in G1 and 124 (83.8\%) were older than 45 at diagnosis (study Group G2). Forty one patients (27.7\%) were diagnosed between $45-60$ years, 74 patients $(50 \%)$ between $60-75$ years and 9 cases $(6.08 \%)$ at an age $>75$ years.

Risk factors distribution and clinical presentation according to age at onset are presented in Table 1. Sex distribution had a 
Table 1. Risk factors and clinical presentation by age at diagnosis

\begin{tabular}{|c|c|c|c|c|}
\hline & & $\begin{array}{c}\text { G1 }(</=45 y) \% \\
(\mathrm{~N}=24)\end{array}$ & $\begin{array}{c}G 2(>45 y) \% \\
(N=120)\end{array}$ & $p$ value \\
\hline Sex & $\begin{array}{l}\text { Male } \\
\text { Female }\end{array}$ & $\begin{array}{l}66.67 \\
33.33\end{array}$ & $\begin{array}{l}46.77 \\
53.23\end{array}$ & 0.07 \\
\hline Smoking & $\begin{array}{l}\text { Yes } \\
\text { No }\end{array}$ & $\begin{array}{l}50.00 \\
50.00\end{array}$ & $\begin{array}{l}28.92 \\
79.92\end{array}$ & 0.06 \\
\hline Alcohol consumption & $\begin{array}{l}\text { Yes } \\
\text { No }\end{array}$ & $\begin{array}{l}42.86 \\
57.14\end{array}$ & $\begin{array}{c}5.41 \\
94.49\end{array}$ & 0.01 \\
\hline Family history of PC & $\begin{array}{l}\text { Yes } \\
\text { No }\end{array}$ & $\begin{array}{l}33.30 \\
66.70\end{array}$ & $\begin{array}{c}1.03 \\
98.97\end{array}$ & 0.0004 \\
\hline Chronic pancreatitis & $\begin{array}{l}\text { Yes } \\
\text { No }\end{array}$ & $\begin{array}{c}0 \\
100\end{array}$ & $\begin{array}{c}6.03 \\
93.97\end{array}$ & 0.59 \\
\hline Obesity & $\begin{array}{l}\text { Yes } \\
\text { No }\end{array}$ & $\begin{array}{c}0 \% \\
100 \%\end{array}$ & $\begin{array}{c}7.89 \% \\
92.11 \%\end{array}$ & 1 \\
\hline Pain & $\begin{array}{l}\text { Yes } \\
\text { No }\end{array}$ & $\begin{array}{l}60 \% \\
40 \%\end{array}$ & $\begin{array}{l}22.94 \% \\
77.06 \%\end{array}$ & 0.006 \\
\hline Jaundice & $\begin{array}{l}\text { Yes } \\
\text { No }\end{array}$ & $\begin{array}{l}57.14 \\
42.86\end{array}$ & $\begin{array}{l}40.91 \\
59.09\end{array}$ & 0.968 \\
\hline Weight loss & $\begin{array}{l}\text { Yes } \\
\text { No }\end{array}$ & $\begin{array}{l}53.33 \\
46.67 \\
\end{array}$ & $\begin{array}{c}67.89 \\
32.11 \\
\end{array}$ & 0.4 \\
\hline
\end{tabular}

marginally significant male predominance in G1 $(p=0.07)$. Of the considered risk factors, alcohol consumption $(\mathrm{p}=0.01)$ and family history of PC $(\mathrm{p}=0.0004)$ were significantly more frequently encountered in G1. The prevalence of chronic pancreatitis, obesity, diabetes mellitus were not significantly different between the two groups, whereas smoking had a marginally significant higher prevalence in $\mathrm{G} 1 \mathrm{p}=0.06)$. Concerning clinical presentation, pain was more often reported by younger patients than by older patients $(p=0.006)$, whereas jaundice and weight loss were similarly distributed in the two groups.

\section{Tumor Characteristics and Treatment}

Tumor features and therapeutic options are depicted in Table 2. Out of the 183 cases with documented pancreatic tumor histology: 148 (80.87\%) were PDACs, 32 (17.5\%) neuro- endocrine tumors, 2 were LMNH and one was mixed adenoneuroendocrine carcinoma (MANEC). In our PDAC study group, tumors were predominantly located in pancreatic head for patients in G1 $(56.52 \%)$, whereas in G2 they were mostly located in the pancreatic body $(52.07 \%, \mathrm{p}=0.02)$. In both groups there was evidence of either vascular invasion or liver metastases in approximately $60 \%$ of cases. Regarding therapeutic options, the differences were not statistically significant between the groups although radical resection was more often conducted in G1 (33.3\% vs $22.69 \%)$. Mortality rates were also similar in the two age groups, around $45 \%$.

\section{Discussion}

We have conducted a retrospective analysis of histologically proven PDACs identifying risk factors for VEOPC. The rate of VEOPC identified in our research is rather high - 
Table 2. Tumor characteristics and therapeutic approach by age at diagnosis

\begin{tabular}{|c|c|c|c|c|}
\hline & & $\begin{array}{c}\mathrm{G1}(</=45 \mathrm{y}) \% \\
(\mathrm{~N}=24)\end{array}$ & $\begin{array}{c}G 2(>45 y) \% \\
(N=120)\end{array}$ & $\mathrm{p}$ value \\
\hline Tumor location & $\begin{array}{c}\text { HEAD } \\
\text { BODY } \\
\text { TAIL }\end{array}$ & $\begin{array}{l}56.52 \% \\
21.74 \% \\
21.74 \%\end{array}$ & $\begin{array}{l}33.06 \% \\
52.07 \% \\
14.88 \%\end{array}$ & 0.02 \\
\hline Vascular invasion & $\begin{array}{l}\text { Yes } \\
\text { No }\end{array}$ & $\begin{array}{l}66.67 \% \\
33.33 \%\end{array}$ & $\begin{array}{l}66.94 \% \\
33.06 \%\end{array}$ & 1 \\
\hline Liver metastases & $\begin{array}{l}\text { Yes } \\
\text { No }\end{array}$ & $\begin{array}{l}68.18 \% \\
31.82 \%\end{array}$ & $\begin{array}{l}60.66 \% \\
39.34 \%\end{array}$ & 0.66 \\
\hline Other metastases & $\begin{array}{l}\text { Yes } \\
\text { No }\end{array}$ & $\begin{array}{l}39.13 \% \\
60.87 \%\end{array}$ & $\begin{array}{l}49.18 \% \\
50.82 \%\end{array}$ & 0.51 \\
\hline Radical resection & $\begin{array}{l}\text { Yes } \\
\text { No }\end{array}$ & $\begin{array}{l}33.33 \% \\
66.67 \%\end{array}$ & $\begin{array}{l}22.69 \% \\
77.31 \%\end{array}$ & 0.39 \\
\hline Adjuvant chemotherapy & $\begin{array}{l}\text { Yes } \\
\text { No }\end{array}$ & $\begin{array}{l}25 \% \\
75 \%\end{array}$ & $\begin{array}{l}20.69 \% \\
79.31 \%\end{array}$ & 0.84 \\
\hline Palliative treatment & $\begin{array}{l}\text { Yes } \\
\text { No }\end{array}$ & $\begin{array}{l}78.26 \% \\
21.74 \%\end{array}$ & $\begin{array}{l}73.04 \% \\
26.96 \%\end{array}$ & 0.79 \\
\hline BSC & $\begin{array}{l}\text { Yes } \\
\text { No }\end{array}$ & $\begin{array}{l}33.33 \% \\
66.67 \%\end{array}$ & $\begin{array}{l}45.05 \% \\
54.95 \%\end{array}$ & 0.41 \\
\hline Death during study period & $\begin{array}{l}\text { Yes } \\
\text { No }\end{array}$ & $\begin{array}{l}42.86 \% \\
57.14 \%\end{array}$ & $\begin{array}{l}44.66 \% \\
55.34 \%\end{array}$ & 1 \\
\hline
\end{tabular}

$16.22 \%$ - by comparison with other reported data, possibly due to the high addressability of our Tertiary Gastroenterology Center. It is also possible that this is a particular feature of our PDAC patient cohort from Eastern Europe as previously reported (4) and this hypothesis warrants further investigation. Taken altogether, the high number of patients with VEOPC has facilitated risk factors analysis in our study. The strength of our study consists is the large number of cases registered consecutively in a standardized manner, during a three years period, using a computerized hospital database. The main draw-back is the retrospective nature of the study.

Our analysis has confirmed alcohol consumption and family history of PC as statistically significant risk factors for VEOPC. Many studies have reported association between EOPC and alcohol consumption and proposed a dosedependent relationship (4-6).
Family history of pancreatic cancer has been identified in up to $10 \%$ of cases in a VEOPCpopulation based study (7) and was associated with elevated risk for EOPC and VEOPC in a study by McWilliams et al. Moreover, certain hereditary syndromes and genetic mutations predispose to EOPC - mutations in tumor suppressor genes, such as TP53 (Li-Fraumeni syndrome), CDKN2A/P16 (FAMM), FA (Fanconi Anemia), or LKB1/STK11 (Peutz-Jeghers syndrome), in genes related to familial PC or cystic fibrosis, or in genes possibly related to other cancer syndromes, such as the breast cancer genes BRCA1 and BRCA2 (10). In other datasets, no difference in morphological features, expression of p53, MLH1, MSH2, c-Erb-2 and no unique immunohistochemical characteristics were identified in EOPC by comparison with PC in older patients (11). Although we did not investigate genetic features in our study, the fact that we have identified 
family history of $\mathrm{PC}$ as a significant risk factor in younger patients supports the genetic predisposition in these cases and warrants further genetic studies in our population.

We found only marginal significance in the association of VEOPC and smoking, possibly due to small sample size. However also a large study by Duffy et. al reported that smoking did not appear to influence the occurrence of $\mathrm{PC}$ in young patients. It is though widely accepted that one of the main acquired risk factors for PC is cigarette smoking and, to a lesser degree, environmental smoking (3). Smoking increases the risk of PC 2-3 fold and it is overrepresented in EOPC population (4). It has also been shown that age at onset of PC is younger in smokers than nonsmokers (8), but debate remains open on this topic (6).

Chronic pancreatitis has been also reported to increase the risk for both VEOPC and EOPC (5) but out data did not support this finding. Regarding diabetes mellitus and obesity, we have obtained similar results to previously published data that reported no risk association with VEOPC (5).

Concerning clinical presentation, abdominal pain was more prevalent in younger patients in our population, which is in concordance to existing data $(1,8)$. Cephalic location of the tumor was significantly more frequently encountered in our patients with VEOPC, contrary to other results presented in the literature $(8,9)$, thus supporting heterogeneity of different pancreatic cancer populations. Tumor location in the pancreatic tail was associated with poor survival in EOPC (9).

Tumor size was also identified as a prognostic factor, a diameter of less than $3 \mathrm{~cm}$ facilitating a radical resection (1). With regard to therapeutic options, radical tumor resection and adjuvant chemotherapy rates were significantly higher in EOPC than NOPC $27 \%$ for potentially curative surgery and $37 \%$ for chemotherapy $(2,7)$. In our study $33.3 \%$ of VEOPC cases vs. $22.69 \%$ of patients in G2 underwent radical surgery and $25 \%$ in G1 vs. $20.69 \%$ in G2 received adjuvant chemotherapy, but the differences were not statistically significant. The high rate of radical resection in our study group could be explained by the fact that our cohort comprised only cases with histologically proven PDAC, and surgery is an important mean of obtaining the histological diagnosis in pancreatic cancer.

We used for initial staging the tumor, node, metastasis (TNM) system of the combined American Joint Committee on Cancer (AJCC)/ Union for International Cancer Control (UICC), eighth edition (2017). A similar prevalence of vascular invasion preventing curative surgery stage T4 and distant metastasis - stage M1 was found in younger and older patients, which is consistent with previous literature $(2,7,8)$.

Survival in PC is less than $5 \%$ at 5 year (2) and is influenced by prognostic factors that include exocrine or endocrine type, stage at diagnosis, location within the pancreas and resectability of the tumor (12). Whether or not the age at onset affects long-term survival is not well-defined (1). Association of resectable EOPC but not of advanced stage EOPC with improved survival, by comparison with same-stage NOPC, suggests that the differences don't result from tumor biology, but rather from other factors (7). Other studies do not report any difference regarding survival between NOPC and $\operatorname{EOPC}(2,9)$. In our analysis death rate during the study period did not differ significantly between age groups.

\section{Conclusion}

Our study has identified alcohol consumption and family history of pancreatic neoplasia as significant risk factors for VEOPC. Clinical presentation is similar between age groups, with the exception of pain, as the primary symptom at diagnosis, in younger patients. In our cohort, therapeutic options and mortality during follow-up do not differ significantly in PDAC patients with age of onset. A better characterization of pancreatic cancer using National Registries could lead to the detection of other age specific risk factors, setting the stage for new genetic studies that will possibly identify better therapeutic stratification, decreasing the significant burden of this disease. 
Conflict of Interest: none declared.

\section{Acknowledgement}

This study has been supported by the Research Grant PN-III-P1-1.2-PCCDI-2017-0797.

\section{References}

1. He J, Edil BH, Cameron JL, Schulick RD, Hruban RH, Herman JM, et al. Young patients undergoing resection of pancreatic cancer fare better than their older counterparts. J Gastrointest Surg. 2013; 17(2):339-44. doi: 10.1007/s11605-012-2066-4. Epub 2012 Nov 27.

2. Tingstedt $B$, Weitkämper $C$, Andersson R, Early onset pancreatic cancer: a controlled trial. Ann Gastroenterol. 2011;24(3): 206-212.

3. Ducreux M, Cuhna AS, Caramella C, Hollebecque A, Burtin P, Goéré $D$, et al. Cancer of the pancreas: ESMO Clinical Practice Guidelines for diagnosis, treatment and follow-up. Ann Oncol. 2015;26 Suppl 5:v56-68. doi: 10.1093/annonc/mdv295.

4. Raimondi S, Maisonneuve P, Löhr JM, Lowenfels AB. Early onset pancreatic cancer: evidence of a major role for smoking and genetic factors. Cancer Epidemiol Biomarkers Prev. 2007;16(9):1894-7.

5. McWilliams RR, Maisonneuve P, Bamlet WR, Petersen GM, Li D, Risch HA, et al. Risk factors for early-onset and very-earlyonset pancreatic adenocarcinoma: a pancreatic cancer case-control consortium (PanC4) analysis. Pancreas. 2016;45(2):311-6. doi: 10.1097/MPA.0000000000000392.

6. Brand RE, Greer JB, Zolotarevsky E, Brand R, Du H, Simeone D, et al. Pancreatic cancer patients who smoke and drink are diagnosed at younger ages. Clin Gastroenterol Hepatol. 2009;7(9):1007-12. doi: 10.1016/j.cgh.2009.06.008. Epub 2009 Jun 26.

7. Duffy A, Capanu M, Allen P, Kurtz R, Olson SH, Ludwig E, et al. Pancreatic adenocarcinoma in a young patient population-12-year experience at Memorial Sloan Kettering Cancer Center. J Surg Oncol. 2009;100(1):8-12. doi: 10.1002/jso.21292.

8. Jiang $Q$, Zhang $S$, Chen $Y$, Zhang J,Wang C. Risk factors for early-onset pancreatic cancer patients and survival analysis. Int $\mathrm{J}$ Clin Exp Med 2017;10(6):9416-9423

9. Beeghly-Fadiel A, Luu H, Du L, Shi C, McGavic D, Parikh A, et al. Early onset pancreatic malignancies: Clinical characteristics and survival associations. Int J Cancer. 2016;139(10):2169-77. doi: 10.1002/ijc.30273. Epub 2016 Aug 22.

10. Frank SA. Age-specific incidence of inherited versus sporadic cancers: a test of the multistage theory of carcinogenesis. Proc Natl Acad Sci U S A. 2005;102(4):1071-5. Epub 2005 Jan 18.

11. Lüttges J1, Stigge C, Pacena M, Klöppel G. Rare ductal adenocarcinoma of the pancreas in patients younger than age 40 years. Cancer. 2004;100(1):173-82.

12. Ries LAG YJ, Keel GE, Eisner MP, Lin YD, Horner M-J (editors). SEER survival monograph: cancer survival among adults: U.S. SEER Program, 1988--2001, patient and tumor characteristics. NIH Bethesda, MD: National Cancer Institute, SEER Program, 2007. 